\title{
Reconstruction Research on Translation Teaching Mode under Constructivism View
}

\author{
Guoxi Chai, Qiaozhi Wen \\ Department of Foreign Languages, Xijing University, Xi'an Shaanxi, 710123, China
}

\begin{abstract}
Keywords: Constructivism view, Translation teaching mode, Reconstruction research.
\end{abstract}
\begin{abstract}
Based on traditional translation teaching mode, this paper proposes basic assumption for innovation of translation teaching mode from the social perspective of constructivism. The author explores reconstruction research on translation teaching mode under constructivism view and hopes to change the redefinition of teacher and student roles through reconstruction research on translation teaching mode so as to effectively improve translation competence of English learners in China and cultivate all-round English talents fir China.
\end{abstract}

\section{Introduction}

Nowadays, the demand level and demand of translation talents in China change greatly. Thus, there are seriously short of translation talents. This means the defects of traditional translation talent training mode become increasingly serious. Thus, relevant education sectors in China carries out fierce discussions on translation talent training mode, such as re-formulating English translation teaching programme, re-propagating English textbooks and conducting innovative teaching test. But these cannot cure the symptoms and only reform traditional translation talent training mode. Deep discussion and reform are not implemented for such education mode. Human behavior mode is often based on certain theoretical basis. This means that in order to innovate for behavior mode, the theory must be transformed. Thus, the fundamental key to translation teaching mode innovation lies in intensive study on the theoretical basis for the purpose of translation teaching mode innovation, or else all attend to trifles and neglect the essentials. We can clearly know from traditional teaching mode that, in traditional translation teaching mode, the teacher is the leading actor in classroom, and the teacher imparts knowledge to students in the form of cramming method. But from the perspective of social constructivism theory, we can clearly know such teaching mode is not suitable for contemporary students at all. Social constructivism holds that knowledge is constructed by learning subjects instead of being transferred. In English translation study, students do not realize the knowledge which they do not know and is independent of their mind, but construct a new cognitive structure through individual experience. This explains the essence of knowledge is construction. The understanding of knowledge essence by social constructivism overturns the understanding of knowledge by objectivism so that people know a new cognitive pattern and rethink whether teacher-centered translation teaching mode is beneficial to English learners. Thus, this paper studies reconstruction of translation teaching mode from the perspective of social constructivism, in the hope of changing traditional translation teaching mode.

\section{Teaching content}

The teacher must bear in mind the idea that "teaching one to fish is better than giving him fish" in English translation class. This means the teacher should become the promoter, collaborator and information resource provider of students' sense construction so as to let students become the leading actors in classroom ${ }^{[1]}$. From the perspective of linguistics, translation practice not just involves transformation of two languages, but represents culture expressed by the two languages. Language is a kind of culture pattern and also a kind of thinking mode. The comparative study on Chinese and English is actually the study on isomorphism of Chinese and isomerism of English. In general sense, 
grammar structure and semantic structure are the meaning of isomorphism of Chinese. Isomorphism of Chinese refers to structure arrangement according to semantic order. Chinese combination does not depend on form sign in grammar in the form. This means Chinese stresses logical meaning and smooth psychological time. The implication of constructivism is that students need to understand the scene through multiple knowledge resources and appropriate information integration so as to solve problems. In the mode, the central factor which connects intuitive space and controls processing is students' self-concept ${ }^{[2]}$. In traditional translation teaching, all data of students come from the teacher. They will never consult the teacher about data source and data selection method. Besides, if students do not ask questions, the teacher will neither actively tell students data source nor make an explanation for students. According to learning theory of constructivism, learning process is that students should take active part in the whole learning activity, including learning material collection and selection. Constructivism requires the teacher to propose appropriate questions in the teaching process so as to arouse students' interest in translation learning and encourage them to gather relevant data. Then, the teacher summaries all data collected by students and chooses the gather teaching objective from the data according to actual conditions ${ }^{[3]}$. Actively gathering data can better arouse students' interest and more effectively motivate students' enthusiasm than giving the data by the teacher. In this way, students can analyze and solve problems actively.

\section{Translation teaching mode reconstruction under constructivism view}

\section{Create situation and guide students to actively construct knowledge.}

In traditional translation teaching, most students consider translation teaching materials are given by the teacher, and they practice just for the purpose of practice. They will never consider who will read the translation and what information they want to gain from the translation. This means translation practice is just for the purpose of translation. Students just repeat a translation skill mechanically, and will never consider actual function of translation. This indicates that when students gain translation practice materials, the teacher should not apply a translation theory or a translation skill at once, but require students to read the fully text and then propose questions to arouse students' thinking, such as the style of translation material, the target reading group and the information to be gained from the translation. Through putting forward relevant questions, the teacher can guide students in a specific scene and let students actively analyze original text and carry out transpositonal consideration before translation. This means the teacher must help students construct knowledge. When the teacher prepares for the class, he (she) must preconceive various problems in advance, guide students to take active part in teaching and let them learn translation methods and skills ${ }^{[4]}$. In traditional translation teaching, the teacher often tirelessly explains a translation skill and then assign tasks to let students practice what they learn in classroom. However, students often do not listen to the teacher carefully, and most of them copy others' assignments. Modern teaching idea advocated by constructivism designs teaching with the opposite thought with traditional teaching. The specific practice is to encourage students to translate in person and record the knowledge they do not comprehend. Then, when the teacher teaches, students know their weak links and will carefully listen and construct their own knowledge structure. This is because students need to apply original knowledge and experience in translation process. From simple wording and sentence-making to integrating the whole text and looking up strange words, they need to practice in person. Simply speaking, this is to combine "learning” and "translation”, and gradually integrate students' knowledge frame so as to effectively improve students' translation level. This means the teacher must break traditional teaching mode, regard students as the leading actors in translation class and let students gradually train independent practical ability and actively construct knowledge in personal feeling and experience of English translation.

\section{Group, cooperate and pay attention to teaching practice.}

Before class, the teacher should divide students into several groups, let group members cooperate by taking the task as the center, then analyze and discuss original text, mainly consider the function of 
the translation, confirm translation strategy and discuss the problems in the translation process. Later, the teacher should modify and polish the translation. It's worth noting that the teacher must let each student participate in each translation link. In practical translation teaching process, the teacher should actively enlighten students' ability of independent study and make them actively construct knowledge in the process of discussing translation, instead of receiving the knowledge passively. In translation teaching practice under constructivism view, the teacher must give students more time for thinking in classroom and practice space, and fully mobilize students' translation enthusiasm according to the features and interests. Translation teaching aims to train students' intercultural communication competence. The specific method is to gain such competence through teaching students basic theory and method of translation. This means the teacher should not just let students grasp the basic method of translation to cope with examinations, but should help them analyze and understand the content learned and especially practicability of learning content so as to fully consider and stimulate their learning motivation. In this way, each student can become an active and capable learner ${ }^{[5]}$. This means in learning process, students should not just accept the knowledge taught by the teacher, but also should construct their knowledge theory while acquiescing knowledge. Any type of translation will have wonderful language, but the key is theoretical rules and skills of translation. Students can clearly know from English skills that these theoretical skills will appear in certain scene, or a specific grammar. Both teachers and students have seen them numerous times. This means even if teachers can be tireless in teaching, but they cannot make sure students can be insatiable in learning. Hence, it is required to blend theoretical methods of translation in teaching practice so as to motivate students' enthusiasm for translation and let students accept translation theories and skills.

\section{Change teacher's role and train students' translation competence.}

Constructivism requires the teacher must change to the organizer of students' active construction of meaning from knowledge imparter in translation classroom. In other words, students become the leading actors in classroom and the teacher becomes students' guide. During finding and solving problems, a democratic and equal teacher-student relation should be established. Besides, students' meaning construction is promoted through communication between the teacher and students and their interactions. Under the guidance of constructivism, the teacher must change traditional cramming teaching method in translation teaching. The teacher should propose meaningful questions fore the article to be translated, and let students think significantly. In this process, the teacher may organize students for discussion and cooperation. But some teachers understand constructivism in such way that translation learning is the matter of students, so they directly give the initiative to students, without guidance of students. Such practice is wrong. The learning advocated by constructivism is not equal to self-study. In translation teaching under the guidance of constructivism, the teacher plays an indispensable role. Only the job content of teacher is changed to the counselor of students, their helper and promoter from traditional and authoritative transfer role. The teacher acts as a go-between.

\section{Conclusion}

The idea of constructivism brings a huge impact on traditional translation class, opens a new field for translation teaching and offers a new concept. Thus, the translation course conforms to the idea of translation teaching reform. It lays emphasis on teaching practice and the approaches for students to gain knowledge, and trains students' habit of discussion and sharing as well as the ability of cooperation. This means the application of teaching practice idea in translation teaching can make translation teaching become more vivid and efficient so as to train more all-round translation talents for China.

\section{References}

[1] Hao Mingxing, Tian Yuan, Sci-tech English translation teaching of universities of science and technology under constructivism view, Intelligence, 2015,01:114. 
[2] Gong Shaohua, Study on language testing backwash effect of colleges in ethnic minority areas and college English classroom teaching mode reform under constructivism view - case study of Institutes Of HulunBuir, Ethnic Education Study, 2015, 26(2702):119-122.

[3] Wang Min, Translation teaching reform of local universities under constructivism view, Journal of Hubei Correspondence University, 2015, 28 (16422):129-130+132.

[4] Wang Lei, Liu Jinding, Interpretation of translation teaching mode localization based on constructivism, Journal of Yunyang Teachers College, 2009, 29 (12905):123-126.

[5] Wang Chunyan, translation teaching mode reform and practice based on constructivism, Journal of Pu'er University, 2015, 31(11506):115-117. 